\title{
FATIGUE AND RUTTING ANALYSIS OF ASPHALTIC PAVEMENT USING "KENLAYER" SOFTWARE
}

\author{
RIND Touqeer Ali ${ }^{\text {a, }}$, JHATIAL Ashfaque Ahmed ${ }^{\text {a }}$, SANDHU Abdul Razzaque ${ }^{\text {a }}$ \\ BHATTI Imtiaz Ali ${ }^{\text {b }}$, AHMED Sajeel ${ }^{\text {a }}$ \\ ${ }^{a}$ Mehran University of Engineering and Technology, Department of Civil Engineering, Shaheed Zulfiqar Ali Bhutto Campus, \\ Khairpur Mirs', Sindh, Pakistan, e-mail: * touqeerali@muetkhp.edu.pk \\ ${ }^{\mathrm{b}}$ Universiti Tun Hussein Onn Malaysia, Faculty of Civil and Environmental Engineering, 86400 Parit Raja, Batu Pahat, Johor, \\ Malaysia
}

Received: 16.05.2019 / Accepted: 21.06.2019/ Revised: 30.08.2019 / Available online: 10.12.2019

DOI: 10.2478/jaes-2019-0024

KEY WORDS: KENLAYER, Rutting Failure, Fatigue Failure, Traditional design, Empirical-Mechanistic Design.

\begin{abstract}
:
Rutting and Fatigue are taken as main premature failures among all distresses, as these distresses have wide effect on performance of pavement. Sudden variation of heavy axle loaded vehicles, improper mix design and traditional design methodologies used in pavement design industries are major factors behind these failures. For proper performance and good serviceability, these premature distresses should be resisted. Thus, there is a need of using a Mechanistic based design methodology like KENPAVE software, so that traditional design errors should be overcome. KENLAYER is a part of KENPAVE software. KENLYER software tool is utilized to calculated accurately stresses and strains in asphaltic pavement that are ultimately used in calculating allowance for rutting and fatigue failure utilizing Asphalt Institute design models or formulas. Resistance to Rutting failure is checked by calculating vertical compressive stress at the top of soil sub-grade layer, while resistance to fatigue failure is checked by calculating horizontal tensile strain at the bottom of asphaltic layer using KENLAYER software tool. Thus, the object of this research study is to analyze a flexible pavement with respect to rutting and fatigue distresses using KENLAYER software tool. For achieving that objective NHA (N-55) section of road in Sehwan Pakistan was taken as a reference pavement. Pavement was analyzed by altering the thicknesses of bituminous courses by \pm 25 percent. From that we obtained total 20 cross-sections to be analyzed using KENLAYER software in terms of Rutting and Fatigue premature failures.
\end{abstract}

\section{INTRODUCTION}

Roads or pavements are inferred as a durable and effectual travelling surface used to give way and bear loads of different vehicular movements. Pavements have main aim to transfer the vehicular heavy load from top layers to the bottom layers called sub-grade. Based on the type of material to be used there are major two types of pavements i.e flexible pavement (Bitumen is used as a binding material) and rigid pavement (Cement is used as a binding material). This research work was done on flexible pavements. Flexible pavements are layered pavements with low modulus of elasticity and low flexural strength and are constructed in such a way that top quality material is placed on top surface because major portion of load is carried by top course, thus top course should be strong enough to take heavy axle loads. Pavements like flexible and rigid plays a vital role in boosting up the economy of any country (Chegenizadeh et al., 2016). Different countries use different types of pavements for their road construction. In Pakistan majority of pavements are constructed of black top pavements. These black top pavements are designed by older traditional methods like AASHTO flexible pavement design methods in our country, that traditional method of pavement design gives uneconomical and un suitable design because these older design approaches are only accurate for the exact conditions for which they were developed and may give inappropriate result outside the range of their variables. But nowadays most common and accurate method of pavement design used is called as EmpiricalMechanistic design method which considers exact condition of the pavement for design. This design approach calculates stresses and strains in the flexible pavement accurately and then those stresses and strains are used in analyzing any pavement

\footnotetext{
* Corresponding author: Touqeer Ali RIND, E-mail: touqeerali@muetkhp.edu.pk
} 
according to rutting and fatigue failure (Srikanth, 2015). Vertical compressive stresses on top of soil sub grade gives idea of rutting failure while Horizontal tensile strain on the bottom of asphaltic layer gives us idea about fatigue failure in the flexible pavement (Nidhi and Nagakumar, 2013; Muniandy et al., 2013). Sudden variation of heavy axle loaded vehicles, improper mix design and traditional design methodologies used in pavement design industries are major factors behind these failures (Chaudry and Memon, 2013). For making a failure resistant surface of flexible pavement it is essential to design thickness of pavement accurately because improper design thickness of a pavement is major factor behind these all premature failures (Behiry, 2012). So, it is very much important to reduce these premature failures by designing pavement using Empirical-Mechanistic design approach for better economical design. Thus, the aim of this research is to use KNLAYER Empirical-Mechanistic design software and to introduce this design approach to the pavement design industries in our country.

\section{LITERATURE REVIEW}

Srikanth (2015) examined the effect of modulus of elasticity and surface layer thickness on performance of pavement using software called KENPAVE. Researcher wanted to examine the effects horizontal tensile strain and vertical compressive stress on pavement performance by taking modulus of elasticity (E) and thickness (h) as main parameters. Results showed that compressive and tensile micro strains decreased on increasing surface thickness. Also, it was concluded that change of surface thickness brought positive changes in reducing distresses in pavements and also reduction in economical cost.

Nidhi and Nagakumar (2013) used KENLAYER software tool in their research work for the computation of pavement responses. Both Linear and non-linear analysis was done to evaluate the tensile strain, compressive stress and pavement surface deflection. Researcher examined that consideration of nonlinearity generated 0.76 percent increment in compressive strain and 23.13 percent decrease in tensile strain. However, use of linear elastic analysis same values were obtained. So according to this research work nonlinear analysis is turned to be more accurate and realistic than linear analysis

Muniandy et al., (2013) compared the performance of asphaltic pavement using different software that is CHEVPC and KENLAYER. Different distress models were used to examine the pavement performance and then comparison were made between these two softwares. It was examined that strain output obtained from KENLAYER were more accurate than CHEVPC software and they recommended to use KENPAVE software for better results. Researcher used Miner's famous equations to calculate allowable number of load repetitions to stop fatigue and rutting failure which is $\mathrm{Nf}=\mathrm{f} 1(\varepsilon \mathrm{t})^{-\mathrm{f} 2}(\mathrm{E})^{-\mathrm{f} 3}$ and $\mathrm{Nd}=\mathrm{f} 4$ $(\varepsilon v)^{-\mathrm{f3}}$.

Damage analysis was performed using KENLAYER program on rutting and fatigue distresses for different sections of pavements (Mutlag, 2012). In this research the effect of variation of thicknesses of binder layer and wearing layer on design life of pavement was examined. For that horizontal tensile strain and vertical compressive strains were computed using software tool called KENPAVE. It was concluded that by increasing the thickness of wearing layer up to 3.94 " the design life increased and with the increase in binder moduli fatigue damage ratio increased and with decrease in binder moduli decreased rutting damage ratio.

Khan et al. (2012) tried to develop a pavement design software tool named as KENPAVE. Object of this research was to design a pavement of various layer thicknesses with respect to road condition and soil condition. For developing of KENPAVE software researcher used various graphs of empirical method graphs such as CBR, GI and AASHTO to obtain a digital software tool called KENPAVE. Outcomes showed that design of this software is very beneficial for the pavement design industries as the design by using software is less time consuming, accurate and easy. Further researcher concluded that designing of pavement using KENPAVE software can also eliminated errors of traditional manual design.

Gedafa (2006) used KENLAYER and HDM-4 software to corelate the performance of flexible pavement. Parameters of corelation were pavement responses in terms of micro strains and calculation of damage ratio. Researcher used a section of highway with 7 layers 6 lane divided highway as a reference section. Results of co-relation showed that design life calculated from HDM-4 software tool was less than the software KENPAVE. Researcher used Miner's (1945) famous equation for the development of model.

Hong et al., (2006) used Finite Element Method (FEM) to evaluate the pavement responses like strains, stresses and deflections. Major input parameters used by the researcher were poisons ratio, elastic modulus and thicknesses of each pavement layer. Researchers calculated vertical compressive stress at the top of sub-grade layer and horizontal tensile strain at the bottom of asphaltic layer and then the damage analysis was preformed for both fatigue and rutting distresses. Researcher used Asphalt Institute (AI) distress models for calculation of pavement responses that are $\mathrm{Nf}=0.0796(1 / \varepsilon \mathrm{t})^{3.291}(1 / \mathrm{E})^{0.854}$ and $\mathrm{Nr}=$ $1.365 \times 10^{-9}(1 / \varepsilon \mathrm{v})^{4.477}$. Finally, it was recommended by the researcher that pavement designers can use this research study as a guideline for pavement designs and calculation of pavement responses.

Chegenizadeh et al., (2016) in this research work researcher used KENLAYER software for modelling of flexible pavement. Researcher changed different input parameters like poisons ratio and modulus of elasticity and calculated output as stress, strains and deflections. Results showed that the values for intermediate and major and intermediate stresses with less thickness have greater values and higher thickness have showed lower values. Also, it was observed that values of minor stresses were much lesser than intermediate and major stresses.

\section{PROBLEM STATEMENT}

Rutting and fatigue premature failures in flexible pavements are taken as the major distresses which cause failures in flexible pavements because of their vibrant effect on design life and pavement performance. Present design methods followed in Pakistan are traditional empirical methods. In these methods design and analysis is totally relay on the experiences of designer or experimental outcomes. These traditional designs than actually limit the failures bellow critical level and thus failures occur. Now a day's other design methods have been 
developed which consider actual condition of the pavement and design the pavement by taking actual parameters of the pavement. Empirical-Mechanistic design method is such type of design method. This design method calculates very accurately strains and stresses in pavements and then these strains and stresses are utilized in calculating allowable number of loading repetitions to stop fatigue and rutting premature failures (Samad, 2012; Gupta et al., 2014). In Pakistan, recently pavements are being designed using Empirical approaches, in which design are based on experimental results or experiences. Different pavement design sectors, i.e. NHA, NESPAK etc are using trial and error based spread sheets for design of pavements. This is because there are different AASHTO and AI design software like DARWin, SW-1 etc which are so highly expensive that these turn out to be uneconomical for design sectors. This research aims at introducing most economical and use friendly software (KENLAYER) to construction industries and government departments and also encouraging them to use latest software and technologies leaving behind the usage of local, old and conventional design procedures.

\section{INTRODUCTION TO KENLAYER SOFTWARE}

Dr. Y. H. Huang is the man who developed KENPAVE software. This is Microsoft based software which can be used for analysis and design of both rigid and flexible pavements. Actually, this software tool has two portions namely KENSLAB and KENLAYER. KENSLAB portion of this software is used for analysis and design of rigid pavements while KENLAYER portion is used for analysis and design of Flexible pavements. This software is used to calculate micro stresses and strains in flexible and rigid pavements. Basically, KENPAVE software performs damage analysis of pavements and it can run up to nineteen layers and various loading conditions like tridem, tandem, single or their combinations. Furthermore, this software can handle up to 12 periods and 12 load groups which are finally summed up for calculating damage caused by failures. Input parameters in KENPAVE software tool are generally layer thicknesses, material properties (modulus of elasticity and poisons ratios), load group, tire pressure and number of stress points for analysis of pavement. KENPAVE gives output in the form of "output as a text", from this micro strains and stresses are calculated for finally obtaining maximum allowable number of loading repetitions to protect rutting and fatigue premature distresses (Huang, 1993). A screen shot of main screen of KENPAVE software is given below (figure 1):

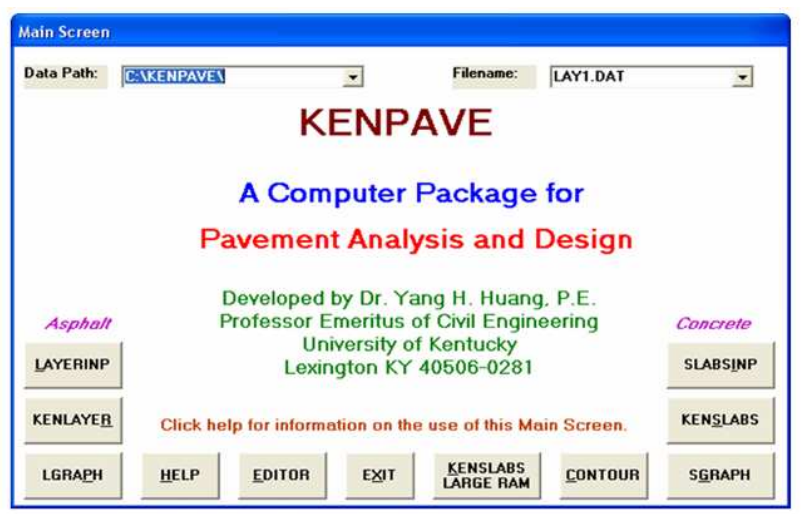

Figure 1. KENPAVE software

\section{RESEARCH METHODOLOGY}

Empirical-Mechanistic pavement design methodology is based on the mechanism of materials which has main input value as wheel loading condition and gives output value as micro stresses and strains which are also called as pavement responses. Main object of this research work was to observe the effect of asphaltic wearing course and asphaltic base course on the pavement performance in terms of rutting and fatigue damage. Thus, to investigate this NHA N-55 section of a road was taken as a references section. Complete research methodology flow chart is given in figure 2 .

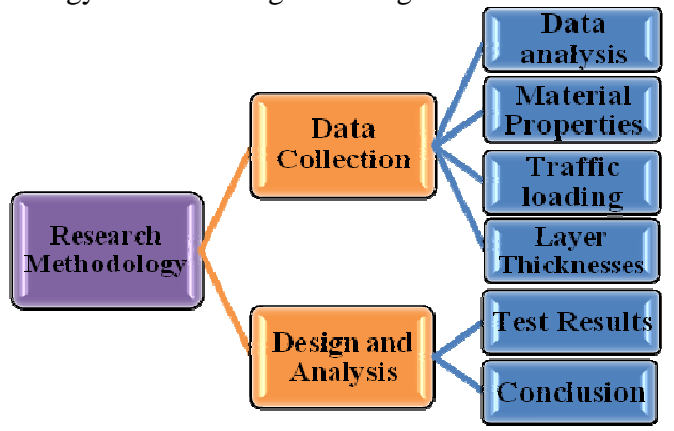

Figure 2. Flow chart of Research Methodology

The N-55 test section has total 5 layers of asphaltic wearing course, asphaltic base course, aggregate base course, Fill material sub-grade and natural sub-grade having thicknesses 2.0", 6.6", 12"and 12" respectively as shown in Fig. 3 (Note: $\mathrm{cm}$ is converted into inches).

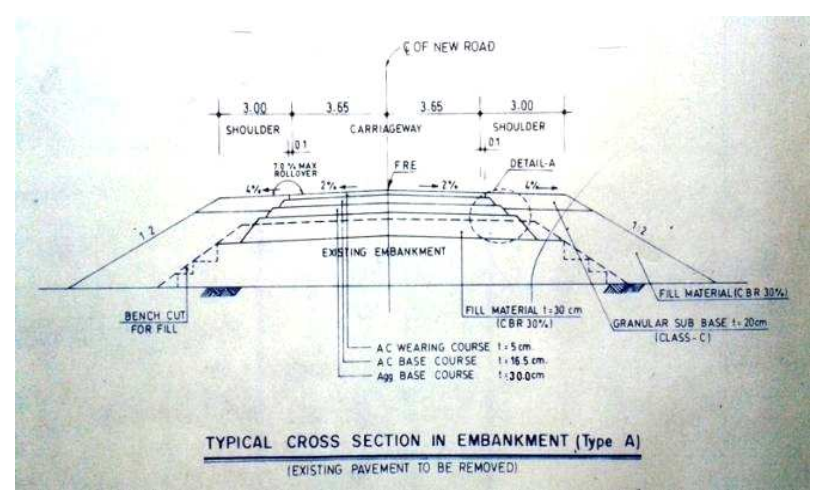

Figure 3. Typical cross-section of flexible pavement

Various cross-sections that can be used in our country for asphaltic wearing and base course are analyzed by altering their thicknesses by $\pm 25 \%$ that is 0.98 " to 2.95 " for asphalt wearing course and 3.25 " to 9.74 "for asphaltic base course. By altering and combining these thicknesses we observed that there are total twenty (20) probable cross-sections and one original section of a pavement that will be analyzed using KENLAYER software. Details of each cross-section are provided in table 1.

Stresses and strains observed from KENLAYER software helped in manually calculating number of load repetitions to prevent rutting and fatigue failure by using Asphalt Institute equations. Section of pavement that gave maximum value of $\mathrm{Nr}$ and $\mathrm{Nf}$ was considered as best section of pavement with respect to pavement responses. Every cross-section was also analyzed from economical point of view by calculating cost of 
construction of asphaltic wearing and base course only. Sample of KENLAYER output as a text is given bellow:

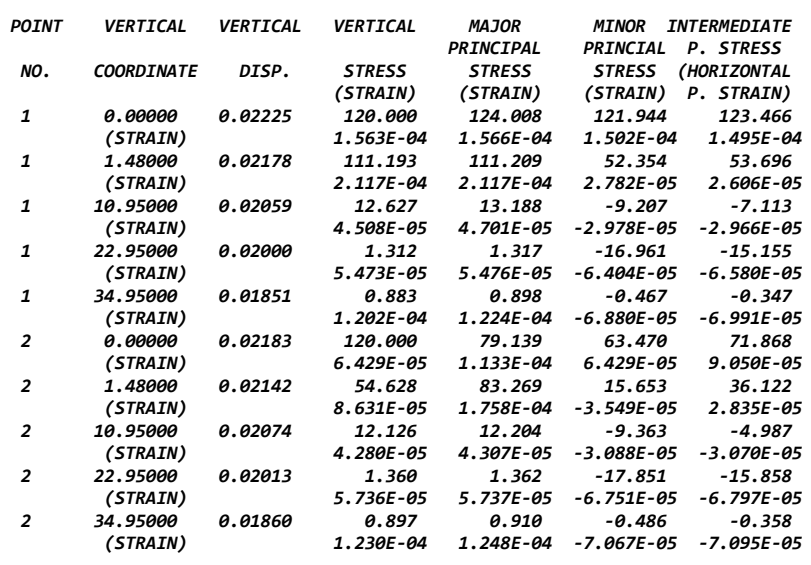

\section{RESULTS AND DISCUSSIONS}

\subsection{General Discussion}

The data utilized in this research work were collected from NHA (National highway authority). Various input parameters like Poisson's ratio, elastic modulus and layer thicknesses were engaged from NHA guidebooks. From NHA guide book Poisson's ratio and elastic modulus for asphaltic wearing course were taken as 0.25 and $400 \mathrm{ksi}$ respectively, Poisson's ratio and elastic modulus for asphaltic base course were taken as 0.2 and $350 \mathrm{ksi}$ respectively, Poisson's ratio and elastic modulus for asphaltic Aggregate base course were taken as 0.3 and 200ksi respectively, Poisson's ratio and elastic modulus for Fill material course were taken as 0.4 and 10ksi respectively and Poisson's ratio and elastic modulus for asphaltic wearing course were taken as 0.45 and $5 \mathrm{ksi}$ respectively. Thicknesses of asphaltic wearing course and asphaltic base course were altered. By doing that we obtained total twenty-one (21) cross-sections for analysis and design purposes as shown in table 1 .

Table 1. Thicknesses of each designed Cross-section

\begin{tabular}{|c|c|c|c|c|c|}
\hline $\begin{array}{l}\text { Cross- } \\
\text { section } \\
\text { number }\end{array}$ & $\begin{array}{c}\text { Thickness } \\
\text { of } \\
\text { Asphaltic } \\
\text { wearing } \\
\text { course }\end{array}$ & $\begin{array}{c}\text { Thickness } \\
\text { of } \\
\text { Asphaltic } \\
\text { base } \\
\text { course }\end{array}$ & $\begin{array}{c}\text { Thickness } \\
\text { of } \\
\text { granular } \\
\text { base } \\
\text { course }\end{array}$ & $\begin{array}{c}\text { Thickness } \\
\text { of fill } \\
\text { material } \\
\text { course }\end{array}$ & $\begin{array}{l}\text { Thickness } \\
\text { of natural } \\
\text { sub-grade }\end{array}$ \\
\hline Natural & $\begin{array}{l}5 \mathrm{~cm} \\
(2.0 ")\end{array}$ & $\begin{array}{l}16.5 \mathrm{~cm} \\
(6.6 ”)\end{array}$ & $\begin{array}{l}30 \mathrm{~cm} \\
(12, ')\end{array}$ & $\begin{array}{l}30 \mathrm{~cm} \\
(12 " ')\end{array}$ & - \\
\hline 1 & $\begin{array}{l}2.5 \mathrm{~cm} \\
\left(0.98^{\prime \prime}\right)\end{array}$ & $\begin{array}{l}16.5 \mathrm{~cm} \\
(6.6 ”)\end{array}$ & $\begin{array}{l}30 \mathrm{~cm} \\
(12, ')\end{array}$ & $\begin{array}{l}30 \mathrm{~cm} \\
(12, ')\end{array}$ & - \\
\hline 2 & $\begin{array}{l}2.5 \mathrm{~cm} \\
\left(0.98^{\prime \prime}\right)\end{array}$ & $\begin{array}{l}8.25 \mathrm{~cm} \\
(3.25 ")\end{array}$ & $\begin{array}{l}30 \mathrm{~cm} \\
\left(12{ }^{\prime} '\right)\end{array}$ & $\begin{array}{l}30 \mathrm{~cm} \\
(12, ')\end{array}$ & - \\
\hline 3 & $\begin{array}{l}2.5 \mathrm{~cm} \\
\left(0.98^{\prime \prime}\right)\end{array}$ & $\begin{array}{l}12.375 \mathrm{~cm} \\
(4.87 ”)\end{array}$ & $\begin{array}{l}30 \mathrm{~cm} \\
\left(12 '{ }^{\prime}\right)\end{array}$ & $\begin{array}{l}30 \mathrm{~cm} \\
\left(12{ }^{\prime} \prime\right)\end{array}$ & - \\
\hline 4 & $\begin{array}{l}2.5 \mathrm{~cm} \\
\left(0.98^{\prime \prime}\right)\end{array}$ & $\begin{array}{l}20.625 \mathrm{~cm} \\
(8.12 ”)\end{array}$ & $\begin{array}{l}30 \mathrm{~cm} \\
\left(12{ }^{\prime \prime}\right)\end{array}$ & $\begin{array}{l}30 \mathrm{~cm} \\
\left(12{ }^{\prime \prime}\right)\end{array}$ & - \\
\hline 5 & $\begin{array}{l}2.5 \mathrm{~cm} \\
(0.98 ”)\end{array}$ & $\begin{array}{l}24.75 \mathrm{~cm} \\
(9.74 ”)\end{array}$ & $\begin{array}{l}30 \mathrm{~cm} \\
\left(12{ }^{\prime \prime}\right)\end{array}$ & $\begin{array}{l}30 \mathrm{~cm} \\
(12 ')\end{array}$ & - \\
\hline 6 & $\begin{array}{l}3.75 \mathrm{~cm} \\
\left(1.48^{\prime \prime}\right)\end{array}$ & $\begin{array}{l}16.5 \mathrm{~cm} \\
(6.6 ”)\end{array}$ & $\begin{array}{l}30 \mathrm{~cm} \\
(12, ')\end{array}$ & $\begin{array}{l}30 \mathrm{~cm} \\
\left(12{ }^{\prime \prime}\right)\end{array}$ & - \\
\hline 7 & $\begin{array}{l}3.75 \mathrm{~cm} \\
\left(1.48^{\prime \prime}\right)\end{array}$ & $\begin{array}{l}8.25 \mathrm{~cm} \\
(3.25 ")\end{array}$ & $\begin{array}{l}30 \mathrm{~cm} \\
\left(12 '{ }^{\prime}\right)\end{array}$ & $\begin{array}{l}30 \mathrm{~cm} \\
\left(12 '{ }^{\prime}\right)\end{array}$ & - \\
\hline 8 & $\begin{array}{l}3.75 \mathrm{~cm} \\
\left(1.48^{\prime \prime}\right)\end{array}$ & $\begin{array}{l}12.375 \mathrm{~cm} \\
(4.87 ”)\end{array}$ & $\begin{array}{l}30 \mathrm{~cm} \\
\left(12 '{ }^{\prime}\right)\end{array}$ & $\begin{array}{l}30 \mathrm{~cm} \\
\left(12{ }^{\prime}\right)\end{array}$ & - \\
\hline 9 & $\begin{array}{l}3.75 \mathrm{~cm} \\
\left(1.48^{\prime \prime}\right)\end{array}$ & $\begin{array}{l}20.625 \mathrm{~cm} \\
(8.12 ")\end{array}$ & $\begin{array}{l}30 \mathrm{~cm} \\
(12 '))\end{array}$ & $\begin{array}{l}30 \mathrm{~cm} \\
(12 '))\end{array}$ & - \\
\hline
\end{tabular}

\begin{tabular}{|c|c|c|}
\hline $\begin{array}{l}3.75 \mathrm{~cm} \\
\left(1.48^{\prime \prime}\right)\end{array}$ & $\begin{array}{l}24.75 \mathrm{~cm} \\
(9.74 ")\end{array}$ & $\begin{array}{l}30 \mathrm{~cm} \\
(12, ')\end{array}$ \\
\hline $6.25 \mathrm{~cm}$ & $16.5 \mathrm{~cm}$ & $30 \mathrm{~cm}$ \\
\hline (2.46”) & (6.6”) & $(12 ' ’)$ \\
\hline $6.25 \mathrm{~cm}$ & $8.25 \mathrm{~cm}$ & $30 \mathrm{~cm}$ \\
\hline (2.46”) & $(3.25 ")$ & $\left(12^{\prime \prime}\right)$ \\
\hline $6.25 \mathrm{~cm}$ & $12.375 \mathrm{~cm}$ & $30 \mathrm{~cm}$ \\
\hline (2.46”) & (4.87”) & $\left(12^{\prime \prime}\right)$ \\
\hline $6.25 \mathrm{~cm}$ & $20.625 \mathrm{~cm}$ & $30 \mathrm{~cm}$ \\
\hline$(2.46 ”)$ & (8.12”) & $\left(12^{\prime \prime}\right)$ \\
\hline $6.25 \mathrm{~cm}$ & $24.75 \mathrm{~cm}$ & $30 \mathrm{~cm}$ \\
\hline$(2.46 ”)$ & (9.74”) & $(12$ '’) \\
\hline $7.5 \mathrm{~cm}$ & $16.5 \mathrm{~cm}$ & $30 \mathrm{~cm}$ \\
\hline (2.95”) & (6.6”) & $(12 " ')$ \\
\hline $7.5 \mathrm{~cm}$ & $8.25 \mathrm{~cm}$ & $30 \mathrm{~cm}$ \\
\hline (2.95”) & $(3.25 ”)$ & $(12 " ')$ \\
\hline $7.5 \mathrm{~cm}$ & $12.375 \mathrm{~cm}$ & $30 \mathrm{~cm}$ \\
\hline$(2.95 ”)$ & (4.87”) & $(12 ')$ \\
\hline $7.5 \mathrm{~cm}$ & $20.625 \mathrm{~cm}$ & $30 \mathrm{~cm}$ \\
\hline$(2.95 ”)$ & (8.12”) & $(12$ '’) \\
\hline $7.5 \mathrm{~cm}$ & $24.75 \mathrm{~cm}$ & $30 \mathrm{~cm}$ \\
\hline (2.95”) & (9.74”) & $\left(12^{\prime \prime}\right)$ \\
\hline
\end{tabular}

We put all parameters in KENLAYER and than KENLAYER gives result in the form of KENLAYER output as a text. Then from output we calculate maximum horizontal tensile strain and vertical compressive stress for each layer. Our main focus is to calculate maximum vertical compressive stress at the top of subgrade course $\left(\boldsymbol{\varepsilon}_{\mathbf{z}}\right)$ and maximum horizontal tensile strain at the bottom of asphaltic layer $\left(\boldsymbol{\varepsilon}_{\mathrm{t}}\right)$. Then these $\left(\boldsymbol{\varepsilon}_{\mathbf{z}}\right)$ and $\left(\boldsymbol{\varepsilon}_{\mathrm{t}}\right)$ will be used in calculating Allowance for load repetitions to stop rutting $(\mathrm{Nr})$ and fatigue failure $(\mathrm{Nf})$.

\subsection{Analysis of KENPAVE Results}

Allowance for load repetitions to stop rutting $(\mathrm{Nr})$ and fatigue failure (Nf) are calculated by using equations by Asphalt Institute (AI) which are given bellow

\section{Equation for Nf (Fatigue failure)}

Equation modeled by AI to calculate allowance for number of load repetitions to stop fatigue failure is given as (Ameri and Khavandi, 2009):

$$
\mathrm{Nf}=0.0796 *(\text { et })^{\wedge}-3.291 * \mathrm{E} 1 \wedge-0.854
$$

\section{Equation for $\mathrm{Nr}$ (Rutting failure)}

Equation modeled by AI to calculate allowance for number of load repetitions to stop rutting failure is given as (Ameri and Khavandi, 2009):

$\mathrm{Nr}=1.36 * 10^{\wedge}-9 *(\text { er })^{\wedge}-4.477$

Obtained maximum horizontal tensile strain and vertical compressive stress and also allowable number of load repetitions to stop fatigue and rutting failure are shown in following charts: 


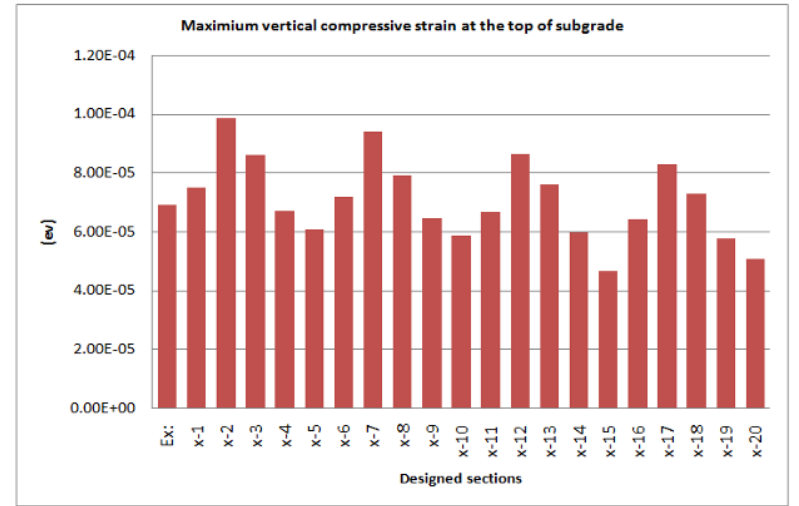

Figure 4. Chart of calculated maximum vertical compressive stress for each cross-section

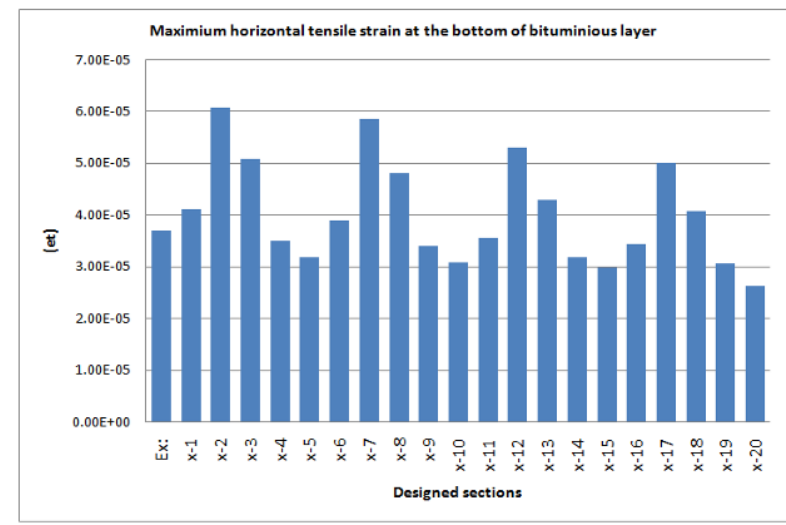

Figure 5. Chart of calculated maximum Horizontal tensile strain for each cross-section

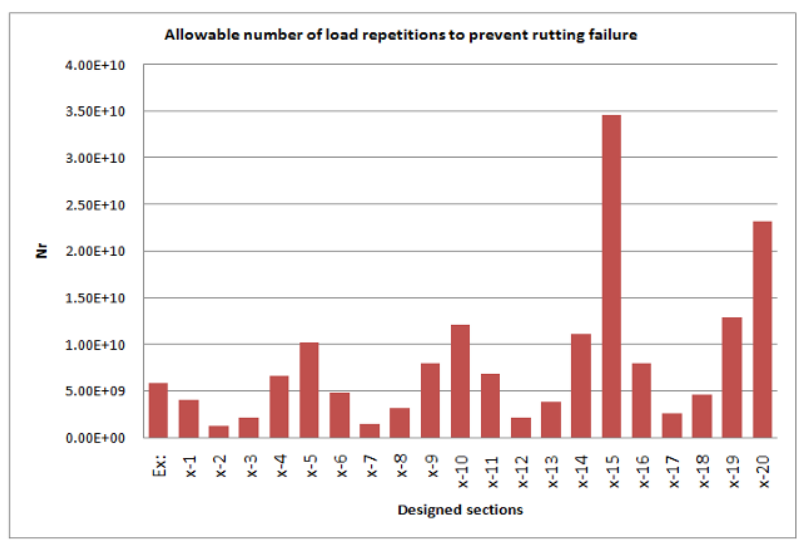

Figure 6. Chart of calculated Allowable num of loading repetitions to stop rutting distress

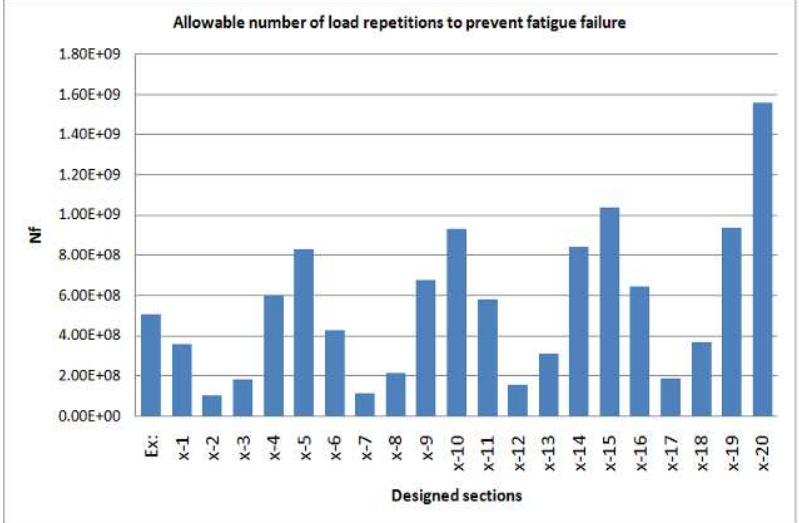

Figure 7. Chart of calculated Allowable num of loading repetitions to stop rutting distress

It is examined from figure 6 and figure 7 that section of pavement number 15 and 20 are giving maximum allowable number of load repetitions to stop rutting and fatigue distresses respectively. Now we must check whether cross-section number 15 is more economical or cross-section number 20. For that we calculated cost of construction of asphaltic wearing course and asphaltic base according to NHA specifications for each section as shown in following figure.

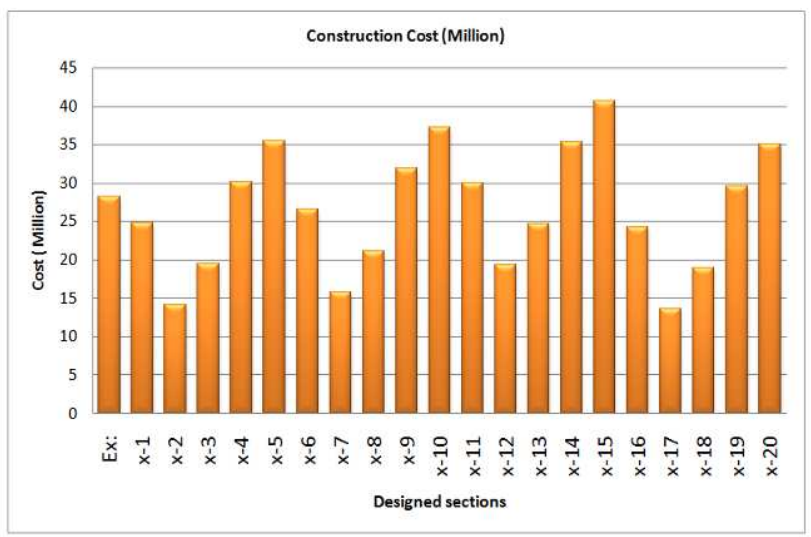

Figure 8. Chart of calculated cost of construction of two layers for each cross-section

Thus, it is clear from the figure 8 of cost analysis that section number 20 is more economical than section number 15 . So, from this research work we as a researcher recommend this cross-section 20 to be constructed as a pavement as it is more failure resistant in terms of fatigue and rutting distresses.

\section{CONCLUSION}

This research work was carried out to analyze the effect of altering the thicknesses of asphaltic wearing and base course thickness on pavement performance. Based upon results following conclusions are made

1. KENPAVE or KENLAYER software tool is used friendly and reliable software and it can be used in highway design industries.

2. As the thickness of asphaltic wearing course and asphaltic base course were increasing, the micro 
strains were decreasing and allowance for number of loading repetition increased.

3. As the thickness of asphaltic wearing course and base course were decreasing, the micro strains were increasing and allowance for number of loading repetition decreased

4. Recommended cross-section from distress resistant point of view is cross-section "20" which gives allowance for loading repetition in terms of fatigue failure as $1.56 E+09$ repetitions of tandem axle load and in terms of rutting failure as $3.46 E+10$ repetitions of tandem axle load.

\section{References:}

Ameri, M. and Khavandi, A. (2009). Development of mechanistic-empirical flexible pavement design in Iran. Journal of Applied Sciences, 9(2), pp. 354-359.

Behiry, A. E. A. E. M. (2012). "Fatigue and rutting lives in flexible pavement." Ain Shams Engineering Journal, 3(4), pp. 367-374. https://doi.org/10.1016/j.asej.2012.04.008.

Chaudry, R., \& Memon, A. B. (2013). "Effects of variation in Truck factor on pavement performance in Pakistan." Mehran University Research Journal of Engineering and Technology, 32(1): $19-30$.

Chegenizadeh, A. and Keramatikerman, M. and Nikraz, H. (2016). "Flexible pavement modelling using Kenlayer." Electronic Journal of Geotechnical Engineering, 21(7): 24672479.

Gedafa, D. S. (2006). "Comparison of flexible pavement performance using KENLAYER and HDM-4." Midwest Transportation Consortium, Ames, Iowa.

Gupta, A., Kumar, P., and Rastogi, R. (2014). "Critical review of flexible pavement performance models." KSCE Journal of Civil Engineering, 18(1): 142 - 148. DOI: 10.1007/s12205014-0255-2.

Hong, F., Pereira, F. M., and Prozzi, J. A. (2006). "Comparison of equivalent single axle loads from empirical and mechanisticempirical approaches." Transportation Research Board Annual Meeting, Transportation Research Board, Washington, DC.

Huang, Y. H. Pavement analysis and design. Prentice Hall 1993: $100-167$.

Khan, R. U., Khan, M. I., \& Khan, A. U. (2012). "Software Development (PAKPAVE) for Flexible Pavement Design." International Journal of Multidisciplinary Sciences And Engineering, 13(11): 1 - 5.

Muniandy, R., Aburkaba, E. and Thamer, N. (2013). "Comparison of flexible pavement performance using Kenlayer and Chev PC software program." Australian Journal of Basic and Applied Sciences, 7(9): 112-119.

Mutlag, S. A. (2012). "Effect Of Binder Layer Properties on Flexible Pavement In Iraq." Al-Qadisiya Journal for Engineering Sciences, 5(4), pp. 466-476.

Nidhi, M. \& Nagakumar, M. S. (2013). "Applications of Layered Theory for the Analysis of Flexible Pavements." International Journal of Research in Engineering and $\begin{array}{lllll}\text { Technology, } & 2(1): & & & \end{array}$ https://doi.org/10.15623/ijret.2013.0213034.

Samad, E. (2012). "Sensitivity Analysis In Flexible Pavement Performance Using Mechanistic Empirical Method (Case Study: Cirebon-Losari Road Segment, West Java)." Journal of the Civil Engineering Forum 20(1): 12.

Srikanth, M. R. (2015). "Study on Effect of Surface Course Thickness and Modulus of Elasticity on Performance of Flexible Pavement using a Software Tool." International Journal of Engineering Research \& Technology, 4(08): 771 774. 